\title{
MODEL FLEXICURITY W POLSCE JAKO ODPOWIEDŹ NA WYZWANIA WSPÓŁCZESNEGO RYNKU PRACY
}

\section{WSTĘP}

Tryb życia i pracy ludzi w XXI wieku podlega gwałtownym zmianom. Coraz mniej ludzi jest zatrudnionych w ramach tradycyjnych umów o pracę na czas nieokreślony, a coraz więcej osób pracuje w ramach elastycznych form zatrudnienia. Przyczyn takich zmian jest wiele, m.in.:

- postępujący proces integracji i globalizacji procesów gospodarczych, któremu towarzyszy konieczność zwiększania poziomu innowacyjności i wydajności, tak by podnieść poziom konkurencyjności,

- rozwój nowych technologii, w szczególności w dziedzinie komunikacji i informacji,

- zmiany społeczno-kulturowe (np. starzenie się społeczeństwa, spadek poziomu dzietności),

- szybka ekspansja sektora usług,

- zawodności państwa i rynku, które prowadzą do niepełnego wykorzystania zasobów pracy i wówczas elastyczne zatrudnienie pozwala ograniczyć skutki ekonomiczno-społeczne bezrobocia i umożliwia powrót części siły roboczej na rynek pracy.

Przyczyny te prowadzą między innymi do liberalizacji prawa pracy i upowszechnienia się tzw. elastycznych form zatrudnienia. Elastyczność zatrudnienia $z$ jednej strony zwiększa konkurencyjność przedsiębiorstw i całych gospodarek, z drugiej zaś - pojawiają się zagrożenia trwałości systemu zabezpieczeń społecznych osób zatrudnionych w ramach tego typu zatrudnienia oraz pogłębia się segmentacja rynku pracy polegająca na wspótistnieniu pracowników dobrze zabezpieczonych (posiadających stabilne zatrudnienie) i niezabezpieczonych. Naprzeciw takim zagrożeniom wychodzi model flexicurity, który stanowi zin- 
tegrowaną strategię równoczesnego zwiększania elastyczności i bezpieczeństwa zatrudnienia.

Celem artykułu jest przedstawienie elementów wchodzących w skład modelu flexicurity i próba oceny stanu ich wdrożenia na polskim rynku pracy. Zaprezentowano w nim także podstawowe założenia, cechy oraz korzyści płynące $z$ wprowadzania modelu flexicurity. Ponadto omówiono wspólne zasady i aspekt finansowy wdrażania modelu flexicurity w Unii Europejskiej.

\section{MODEL FLEXICURITY - POJĘCIE, CECHY I KORZYŚCI}

Pojęcie flexicurity odnosi się do poszukiwania rozwiązań korzystnych dla pracodawcy i pracownika, a powstało w wyniku połączenia słów flexibility - trudność pogodzenia potrzeb pracodawcy z uwarunkowaniami pracownika, co stwarza konieczność wypracowania metod poszukiwania równowagi między elastycznością rynku pracy, oraz security, tzn. bezpieczeństwo socjalne ${ }^{1}$.

Flexicurity można określić jako zintegrowaną strategię równoczesnego zwiększania elastyczności i bezpieczeństwa zatrudnienia. Stanowi kompleksowe podejście do tworzenia polityki rynku pracy, łącząc elastyczność umów z zapewnieniem pracownikom bezpieczeństwa w zakresie możliwości zachowania miejsca pracy bądź znalezienia w krótkim czasie nowej pracy, i to na każdym etapie życia zawodowego, jak również do tworzenia szans rozwoju zawodowego w warunkach szybko zmieniającej się gospodarki. Elastyczność oznacza także elastyczną organizację pracy, która ułatwia godzenie życia prywatnego z zawodowym. Z kolei bezpieczeństwo w modelu flexicurity nie polega tylko na zapewnieniu trwałości aktualnego zatrudnienia, lecz na wyposażeniu ludzi w takie umiejętności, które umożliwią im rozwój zawodowy i ułatwią znalezienie nowej pracy. Ważnym elementem modelu jest tu zapewnienie świadczeń ułatwiających przetrwanie okresu przejściowego $^{2}$.

$\mathrm{Na}$ rynku pracy model flexicurity funkcjonuje jako tzw. złoty trójkąt, którego wierzchołkami są: elastyczne przepisy dotyczące zatrudnienia prowadzące do wysokiej elastyczności liczbowej, rozbudowany system wsparcia zapewniajacy bezpieczeństwo socjalne oraz powszechne działania aktywizacyjne i edukacyjne motywujące bezrobotnych do poszukiwania pracy, pozwalające im uzyskać kwalifikacje niezbędne do ponownego wejścia na rynek pracy ${ }^{3}$.

${ }^{1}$ M. Rymsza (red.), Elastyczny rynek pracy i bezpieczeństwo socjalne. Flexicurity po polsku?, Instytut Spraw Publicznych, Warszawa 2005, s. 9.

2 Europe's Social Reality, BEPA 2007, s. 11.

${ }^{3}$ Ibidem, s. 10-11. 
W Europie, a także w Polsce dynamicznie postępuje proces uelastyczniania rynku pracy, czego przejawem jest upowszechnianie się nietypowych form zatrudnienia, które uzupełniają, a częściowo zastępują typowe zatrudnienie pracownicze. Zjawisko to znajduje odzwierciedlenie także w dokumentach Unii Europejskiej - np.w Strategii Lizbońskiej, która akcentuje potrzebę upowszechniania w Europie nietypowych form zatrudnienia przy równoczesnym obejmowaniu możliwie pełną ochroną socjalną „nietypowych pracowników”.

Oprócz dokumentów UE także Organizacja Współpracy Gospodarczej i Rozwoju (OECD) podaje cechy charakterystyczne dla modelu flexicurity. Należą do nich:

- umiarkowana ochrona zatrudnienia,

- wysoki poziom uczestnictwa w programach uczenia się przez całe życie,

- wysoki poziom wydatków na politykę (zarówno pasywną, jak i aktywną),

- systemy świadczeń dla bezrobotnych, zapewniające wysokie świadczenia, ale przy zrównoważeniu praw i obowiązków,

- szeroki zakres zabezpieczeń społecznych,

- wysoki udział związków zawodowych.

Zasadniczy problem, jaki nasuwa się w przypadku prowadzenia polityki flexicurity, dotyczy połączenia w obrębie jednego rynku pracy dwóch, wydawać by się mogło, wykluczających się kwestii - elastyczności zatrudnienia i bezpieczeństwa socjalnego, stąd często stawiane jest pytanie, czy we współczesnej gospodarce, w systemie danego państwa mogą ze sobą współgrać takie czynniki, jak: wysoki poziom zatrudnienia, niska stopa bezrobocia, elastyczne przepisy prawa pracy i bezpieczeństwo socjalne, przy jednoczesnym utrzymywaniu sprawnego systemu finansów publicznych? W opinii Maartena Keune z Europejskiego Instytutu Związków Zawodowych, flexicurity jest koncepcją otwartą i umożliwia łączenie elastyczności i bezpieczeństwa na wiele sposobów. Można bowiem mówić o czterech typach elastyczności ${ }^{4}$ :

- zewnętrznej - np.: outsourcing pracowniczy, dzielenie się pracownikami, leasing pracowniczy $\mathrm{i}$ inne niestandardowe formy zatrudnienia;

- wewnętrznej - elastyczny czas pracy (praca w niepełnym wymiarze godzin, skompresowany czas pracy, przerywany czas pracy, praca w weekendy, praca w wydłużonym okresie rozliczeniowym, praca w nadgodzinach, elastyczne godziny pracy w skali dnia);

- funkcjonalnej - wielozadaniowość pracowników, praca na zastępstwo, podział stanowisk pracy, praca na zmiany, praca na akord, telepraca, offshoring;

${ }^{4}$ K. Belczyk, Flexicurity - elastyczne bezpieczeństwo na rynku pracy, http://www.rynekpracy. pl/artykul.php/wpis.51. 
- płacowej - płaca powiązana z wynikami, zmiana struktury wynagrodzeń: niższe wynagrodzenia zasadnicze w zamian za wyższe bonusy zależne od efektów pracy, udział w zysku firmy oraz opcje na akcje firmy.

Ponadto należy podkreślić, że bezpieczeństwo nie jest postrzegane jako pewność utrzymania konkretnego etatu, lecz jako pewność zatrudnienia w ogóle. W związku z tym bezpieczeństwo w modelowym ujęciu flexicurity będzie obejmowaćs:

- bezpieczeństwo pracy - ochrona przez zwolnieniami,

- bezpieczeństwo zatrudnienia - zdolność do zatrudnienia dzięki uzyskaniu odpowiedniego wykształcenia oraz szkoleniom,

- bezpieczeństwo dochodu - zasiłki dla bezrobotnych, ubezpieczenia społeczne,

- bezpieczeństwo kombinacji - równowaga pomiędzy pracą a życiem prywatnym.

Eksperci OECD podkreślają, że wdrażanie flexicurity może być korzystne zarówno dla pracowników, jak i dla przedsiębiorstw. Elastyczność oznacza bowiem stworzenie warunków, w których pracownicy będą mogli łatwo zdobyć lub zmienić pracę, a poprawa ich kwalifikacji zwiększy bezpieczeństwo i korzyści pracodawcy. Dzięki modelowi flexicurity także pracownicy czują się bezpieczni i łatwiej w razie potrzeby mogą zmienić zajęcie. Pracodawca z kolei szybciej może pozyskać pożądanych fachowców.

Podkreśla się też często, że efektem stosowania elastycznych form zatrudnienia jest wzrost kapitału ludzkiego - produktywności, zdrowotności pracowników, zadowolenia $z$ wykonywanej pracy, atrakcyjności zatrudnienia, lojalności wobec firmy, wolności wyboru, możliwości zatrudnienia osób dotąd nieobecnych na rynku pracy. Istotna jest również możliwość rozwoju osobistego pracownika, stałego podnoszenia kwalifikacji i nabywania nowych kompetencji, a także lepszego pogodzenia życia rodzinnego z życiem zawodowym.

Korzyściami dla pracodawców są najczęściej obniżenie kosztów pracy, optymalizacja struktury zatrudnienia i zwiększenie jej efektywności, łatwiejsze pozyskiwanie ekspertów, elastyczna adaptacja firmy do zmian rynkowych, a w konsekwencji wzrost konkurencyjności przedsiębiorstwa.

${ }^{5}$ Komisja Europejska, Dziesięć lat europejskiej strategii zatrudnienia (ESZ), Luksemburg 2007, 


\section{ELEMENTY MODELU FLEXICURITY}

W dokumentach Unii Europejskiej przyjęto, że w celu osiągnięcia równowagi między elastycznością i bezpieczeństwem na rynku pracy konieczne jest spełnienie czterech warunków, takich jak ${ }^{6}$ :

- dostępność właściwych (elastycznych i bezpiecznych) porozumień umownych,

- aktywna polityka rynku pracy,

- wiarygodne systemy uczenia się przez całe życie,

- nowoczesne systemy zabezpieczenia społecznego.

Pierwszy $z$ warunków, czyli elastyczne i bezpieczne porozumienia umowne, dotyczy przede wszystkim możliwości wykorzystania nietypowych form zatrudnienia, zapewniających elastyczność pracy i jednocześnie redukujących segmentację rynku pracy oraz rozmiary pracy nierejestrowanej. Częścią porozumień umownych jest także wyraźne zaakcentowanie związku między wydajnością pracy a wynagrodzeniem za jej świadczenie.

Warunek drugi - aktywna polityka rynku pracy - to skuteczna pomoc ludziom w zmaganiu się ze zmianami na rynku pracy, zwłaszcza $z$ okresami bezrobocia i przechodzeniem do nowej pracy. Aktywna polityka rynku pracy powinna wspierać stronę popytową rynku i tworzyć nowe miejsca pracy, z drugiej zaś ma oddziaływać na samych pracowników, zapewniać im możliwość przekwalifikowania, doradztwa i pośrednictwa pracy.

Kolejny, trzeci warunek to wiarygodne systemy „uczenia się przez całe życie”, co powinno zapewnić pracownikom stałą przystosowalność i zdolność do zatrudnienia. Czynnik ten ma coraz większe znaczenie, gdyż dobre wykształcenie wstępne, szeroki wachlarz kluczowych kompetencji i stałe inwestowanie w kwalifikacje zwiększają szanse firm na dostosowanie się do zmian w gospodarce, pracownikowi zaś dają szanse utrzymania zatrudnienia lub znalezienia nowej pracy. Wysoki wskaźnik uczestnictwa w działaniach z zakresu uczenia się przez całe życie jest powiązany $\mathrm{z}$ wysoką stopą zatrudnienia i niską stopą, głównie długoterminowego, bezrobocia ${ }^{7}$. Należy podkreślić, że w ramach obszaru „nauka przez całe życie" Komisja Europejska wyróżniła trzy grupy działań8:

- Instrumenty zwiększające zaangażowanie przedsiębiorstwa w szkolenie, m.in.: zachęty podatkowe i finansowe (pożyczki i dopłaty na szkolenia dla MSP), nagrody dla przedsiębiorstw szkolących, obowiązkowa partycypacja

${ }^{6}$ E. Kryńska, Równowaga między elastycznościq i bezpieczeństwem na polskim rynku pracy. Jak osiagnać flexicurity?, „Monitor Prawa Pracy” 2007, nr 7, s. 8. 2007, s. 7.

${ }^{7}$ Wspólne zasady wdrażania modelu flexicurity, Komisja Wspólnot Europejskich, Bruksela

${ }^{8}$ K. Marchlewska, Flexicurity, czyli elastycznośc i bezpieczeństwo w ramach unijnego rynku pracy, Wyższa Szkoła Gospodarki w Bydgoszczy, Bydgoszcz 2008, s. 34. 
finansowa pracodawcy, organizacje parasolowe, programy partnerstwa wspomagające MSP.

- Instrumenty zwiększające zaangażowanie pracowników w szkolenie, stosuje się tutaj płatne urlopy szkoleniowe, indywidualne konta szkoleniowe, talony szkoleniowe i szkolenia w czasie wolnym.

- Instrumenty zwiększające jakość i przejrzystość nabywanych kwalifikacji obejmują tu certyfikowanie umiejętności czy wdrażanie normy ISO 9000.

Omówione powyżej instrumenty powinny stanowić wsparcie realizacji założeń modelu flexicurity.

Ostatni warunek to nowoczesne systemy zabezpieczenia społecznego, czyli takie, które łączą zastosowanie środków wsparcia dochodu z potrzebą stworzenia warunków umożliwiających mobilność na rynku pracy. Wspieraniu dochodu powinny towarzyszyć prawa i obowiązki odnoszące się do możliwości pracy lub szkolenia zawodowego dla zapewnienia powiązania z rynkiem pracy. Systemy ochrony socjalnej powinny wyposażyć ludzi w zdolności przystosowawcze do zmian zachodzących w cyklu życia, aby mieli większe poczucie bezpieczeństwa i postrzegali zmiany na rynku pracy bardziej jako szansę i część życia zawodowego, którą da się zaakceptować, niż jako zagrożenie. Warunek ten obejmuje również usunięcie wszystkich restrykcji ograniczających mobilność pracowników w ramach UE. Podkreśla się, że dobrze rozwinięty system zabezpieczenia społecznego w postaci np. ubezpieczeń od bezrobocia (funkcjonujący od 1994 r. w Danii) bądź gwarancji otrzymywania wysokich świadczeń do czasu znalezienia pracy powinien zredukować obawy pracowników przed niepewnością dochodu.

\section{WSPÓLNE ZASADY WDRAŻANIA MODELU FLEXICURITY W UNII EUROPEJSKIEJ}

Polityka z zakresu flexicurity w Unii Europejskiej musi odzwierciedlać bardzo zróżnicowaną sytuację w różnych krajach, jednak wszystkie państwa członkowskie UE stoją przed tymi samymi wyzwaniami związanymi z modernizacją, przystosowaniem się do globalizacji i zmian otoczenia, w jakim funkcjonują. Dlatego też, aby ułatwić krajowe debaty dotyczące celów strategii na rzecz wzrostu gospodarczego i zatrudnienia, należy wypracować na poziomie Unii Europejskiej pewną liczbę „wspólnych zasad wdrażania modelu flexicurity”. Te wspólne zasady mogłyby być punktem odniesienia, pomocnym w budowaniu bardziej otwartych i dynamicznych rynków pracy i bardziej wydajnych miejsc pracy. Powinny one pomóc państwom członkowskim w tworzeniu i wdrażaniu strategii w zakresie flexicurity, w taki sposób, aby w pełni uwzględnić charakterystyczne dla danego 
kraju problemy, szanse i okoliczności oraz zagwarantować zaangażowanie partnerów społecznych w promocję i wdrażanie modelu flexicurity.

Tabela 1. Przykładowe wspólne zasady wdrażania modelu flexicurity w UE

\begin{tabular}{|c|c|}
\hline $\begin{array}{l}\text { ZASADA } \\
1\end{array}$ & $\begin{array}{l}\text { Model flexicurity obejmuje elastyczne i przewidywalne warunki umów (zarówno z perspek- } \\
\text { tywy pracodawcy, jak i pracownika, osób posiadających stabilne zatrudnienie i nieposiadają- } \\
\text { cych stabilnego zatrudnienia), kompleksowe strategie uczenia się przez całe życie, skuteczną } \\
\text { aktywną politykę rynku pracy oraz nowoczesne systemy zabezpieczeń społecznych. Jego ce- } \\
\text { lem jest wsparcie wdrażania strategii na rzecz wzrostu gospodarczego i zatrudnienia, tworze- } \\
\text { nie większej liczby lepszych miejsc pracy i wzmocnienie europejskich modeli społecznych } \\
\text { poprzez określenie nowych form elastyczności i bezpieczeństwa, zwiększających zdolności } \\
\text { dostosowawcze, zatrudnienie i spójność społeczną. }\end{array}$ \\
\hline $\begin{array}{l}\text { ZASADA } \\
2 \\
\end{array}$ & $\begin{array}{l}\text { Model flexicurity oznacza zrównoważenie praw i obowiązków pracodawców, pracowników, } \\
\text { osób poszukujących pracy i władz publicznych. }\end{array}$ \\
\hline $\begin{array}{l}\text { ZASADA } \\
3\end{array}$ & $\begin{array}{l}\text { Model flexicurity powinien być dostosowany do szczególnych warunków, cech rynku pracy } \\
\text { i stosunków przemysłowych charakteryzujących dane państwo członkowskie. Nie chodzi } \\
\text { natomiast o wprowadzenie jednego modelu rynku pracy lub jednej strategii politycznej. }\end{array}$ \\
\hline $\begin{array}{l}\text { ZASADA } \\
\quad 4\end{array}$ & $\begin{array}{l}\text { Model flexicurity powinien zredukować różnice dzielące osoby posiadające stabilne za- } \\
\text { trudnienie i nieposiadające takiego zatrudnienia. Osoby zatrudnione na stałe powinny } \\
\text { otrzymywać wsparcie, by były przygotowane na zmianę pracy i chronione w trakcie takiej } \\
\text { zmiany. Dla osób obecnie niemających stałego zatrudnienia - w tym należących do grupy } \\
\text { osób niemających żadnej pracy, w której reprezentowane są kobiety, ludzie młodzi i imigranci } \\
\text { - należy stworzyć możliwości łatwego wejścia na rynek pracy i środki pomagające w zmianie } \\
\text { warunków umów na bardziej stabilne. }\end{array}$ \\
\hline $\begin{array}{l}\text { ZASADA } \\
5\end{array}$ & $\begin{array}{l}\text { Należy wspierać model flexicurity zarówno w wymiarze wewnętrznym (w przedsiębior- } \\
\text { stwach), jak i zewnętrznym (w stosunkach między przedsiębiorstwami). Odpowiedniej ela- } \\
\text { styczności w zakresie zatrudniania i zwalniania towarzyszyć musi zabezpieczenie na okres } \\
\text { zmiany pracy. Należy ułatwić awansowanie w pracy, a także przechodzenie ze stanu bezrobo- } \\
\text { cia lub braku zatrudnienia do stanu zatrudnienia. Do celów przyświecających modelowi flexi- } \\
\text { curity należą też: wysokiej jakości miejsca pracy kierowane przez kompetentnych ludzi, dobra } \\
\text { organizacja pracy i stałe podnoszenie kwalifikacji. Zabezpieczenia społeczne powinny wspie- } \\
\text { rać mobilność, a nie ją utrudniać. }\end{array}$ \\
\hline $\begin{array}{l}\text { ZASADA } \\
6\end{array}$ & $\begin{array}{l}\text { Model flexicurity powinien wspierać równość płci poprzez promowanie równego dostępu } \\
\text { do dobrej pracy dla kobiet i mężczyzn i tworzenie możliwości godzenia pracy i życia prywat- } \\
\text { nego, a także równość szans dla imigrantów, ludzi młodych, niepełnosprawnych i starszych } \\
\text { pracowników. }\end{array}$ \\
\hline $\begin{array}{l}\text { ZASADA } \\
7\end{array}$ & $\begin{array}{l}\text { Wdrożenie tego modelu wymaga stworzenia klimatu zaufania i prowadzenia dialogu } \\
\text { między władzami publicznymi a partnerami społecznymi, aby wszystkie strony były przy- } \\
\text { gotowane na podjęcie odpowiedzialności za zmiany, a opracowane zestawy środków były } \\
\text { odpowiednio wyważone. }\end{array}$ \\
\hline $\begin{array}{l}\text { ZASADA } \\
8\end{array}$ & $\begin{array}{l}\text { Polityka w zakresie flexicurity łączy się z kosztami budżetowymi, w związku z tym należy } \\
\text { ją realizować w taki sposób, aby przyczyniała się ona do stabilności i finansowej trwało- } \\
\text { ści polityki budżetowej. W polityce tej powinno się także dążyć do sprawiedliwego podziału } \\
\text { kosztów i korzyści, szczególnie między przedsiębiorstwami, osobami prywatnymi i środkami } \\
\text { publicznymi, a przede wszystkim zwracać uwagę na specyficzną sytuację małych i średnich } \\
\text { przedsiębiorstw. Skuteczna polityka w zakresie flexicurity może się równocześnie przyczynić } \\
\text { do realizacji powyższego ogólnego celu. }\end{array}$ \\
\hline
\end{tabular}

Źródło: opracowanie własne na podstawie Wspólne zasady wdrażania modelu flexicurity, Komisja Wspólnot Europejskich, Bruksela 2007, s. 10-11. 
Tabela 2. Przykłady rozwiązań zalecanych przez Komisję Europejską w poszczególnych obszarach modelu flexicurity

\begin{tabular}{|c|c|}
\hline $\begin{array}{l}\text { WARUNKI } \\
\text { UMÓW }\end{array}$ & $\begin{array}{l}\text { - Poprawa pozycji osób pracujących na umowach na czas określony, umowach agencyj- } \\
\text { nych, na wezwanie itp. Zapewniłaby ona odpowiednią ochronę tych pracowników, np. równą } \\
\text { płacę oraz minimalną liczbę godzin pracy dla pracowników na wezwanie. Przysługiwałyby } \\
\text { im również świadczenia związane z zatrudnieniem, np. objęcie pracowniczymi funduszami } \\
\text { emerytalnymi oraz dostęp do szkoleń. Ustawodawstwo i umowy zbiorowe przewidywałyby } \\
\text { ograniczenie wielokrotnego stosowania niestandardowych umów i promowałyby zmiany wa- } \\
\text { runków umów na korzystniejsze w odpowiednim czasie. } \\
\text { - Środkiem uzupełniającym byłaby zmiana warunków umów na czas nieokreślony. W ra- } \\
\text { mach tej opcji pracownikom oferowano by umowę na czas określony od momentu nawiąza- } \\
\text { nia stosunku pracy z danym pracodawcą; nie byłaby ona poprzedzona serią umów na czas } \\
\text { określony lub umów agencyjnych, jak to często ma miejsce obecnie. Umowa na czas określo- } \\
\text { ny miałaby zmienioną formę, obejmującą stopniowe zwiększanie ochrony przed zwolnie- } \\
\text { niem. Początkowo ochrona ta miałaby zakres podstawowy, który następnie byłby stopniowo } \\
\text { powiększany wraz z rosnącym stażem pracy, aż do osiągnięcia pełnej ochrony. To podejście } \\
\text { „ochrony zależnej od stażu pracy" gwarantowałoby automatyczne uzyskiwanie coraz lepszych } \\
\text { warunków umownych, co zmniejszyłoby ryzyko trwałego zatrzymania się pracownika na } \\
\text { etapie umów oferujących mniejszą ochronę. } \\
\text { - W przypadku umów na czas nieokreślony przewidziano by zmianę zasad zwolnień ze } \\
\text { względów ekonomicznych, zmierzającą do rozwiązania problemów wynikających z biuro- } \\
\text { kracji i długich procedur oraz do poprawy przejrzystości wyników i wiarygodności całego } \\
\text { procesu. }\end{array}$ \\
\hline $\begin{array}{l}\text { UCZENIE } \\
\text { SIĘ PRZEZ } \\
\text { CAŁE ŻYCIE }\end{array}$ & $\begin{array}{l}\text { - Pracodawcy i organy publiczne powinny współpracować w celu poprawy możliwości odby- } \\
\text { wania szkoleń przez pracowników tymczasowych. } \\
\text { - W celu zapewnienia wszystkim możliwości korzystania ze szkoleń właściwe byłoby stwo- } \\
\text { rzenie funduszy i instytutów szkoleniowych na poziomie branżowym lub regionalnym, a dla } \\
\text { zwiększenia liczby uczestników należy zwiększyć zachęty dla pracowników i przedsiębiorstw, } \\
\text { w tym wkład finansowy i ulgi podatkowe. }\end{array}$ \\
\hline $\begin{array}{l}\text { AKTYWNA } \\
\text { POLITYKA } \\
\text { RYNKU } \\
\text { PRACY }\end{array}$ & $\begin{array}{l}\text { - Wzmocnienie publicznych służb zatrudnienia pod względem liczebności i kwalifikacji per- } \\
\text { sonelu. } \\
\text { - Należy rozważyć współpracę z partnerami rynkowymi, np. agencjami pracy tymczasowej. } \\
\text { - Aktywne polityki rynku pracy powinny być formułowane tak, aby wspierać nie tylko osoby } \\
\text { bezrobotne (długoterminowo), ale również te, którym często zdarzają się okresy bezrobocia. }\end{array}$ \\
\hline $\begin{array}{l}\text { SYSTEMY } \\
\text { ZABEZPIE- } \\
\text { CZENIA } \\
\text { SPOŁECZ- } \\
\text { NEGO }\end{array}$ & $\begin{array}{l}\text { - Systemy powinny gwarantować stopniowe zwiększanie się uprawnień pracowników tym- } \\
\text { czasowych, a także doprowadzić do większej możliwości przenoszenia uprawnień pomiędzy } \\
\text { przedsiębiorstwami lub branżami. } \\
\text { - Model uprawnień zmienić w kierunku oferowania wyższych zasiłków w ciągu krótszych } \\
\text { okresów bezrobocia. } \\
\text { - Należy rozważyć wprowadzenie systemu pomocy społecznej zwiększającej mobilność oby- } \\
\text { wateli i zmniejszającej ich zależność od nieformalnej pomocy ze strony rodziny. }\end{array}$ \\
\hline
\end{tabular}

Źródło: opracowanie własne na podstawie Wspólne zasady wdrażania modelu flexicurity..., Bruksela 2007, s. 16.

Wdrożenie wspólnych zasad flexicurity w państwach członkowskich Unii wymaga precyzyjnego zaplanowania ścieżek realizacji modelu. $Z$ uwagi jednak na fakt, że sytuacja społeczno-gospodarcza państw członkowskich, ich kultura i instytucje znacznie się różnią, konkretne działania także mogą się od siebie różnić. Należy podkreślić, iż celem flexicurity nie jest stworzenie jednolitego modelu rynku pracy ani jednolitej strategii wdrażania polityki, jednak dzięki przykładom dobrych rozwiązań stosowanych w Unii Europejskiej państwa członkowskie mogą 
uczyć się od siebie nawzajem, analizując, jakie podejście najlepiej odpowiada ich konkretnym potrzebom. Przykłady rozwiązań prezentuje tab. 2 (s. 324).

\section{ASPEKT FINANSOWY WDRAŻANIA MODELU FLEXICURITY}

Przyspieszenie zmian gospodarczych i przemian rynku pracy powoduje, że pracownicy są zmuszeni do częstszych zmian pracy w ciągu swojego życia zawodowego. Sytuacja taka może łączyć się z koniecznością pobierania świadczeń dla bezrobotnych i korzystania z pomocy w aktywnym poszukiwaniu pracy i podwyższaniu kwalifikacji.

W krajach, w których działa system świadczeń dla bezrobotnych, a zasitki są wysokie, wprowadzenie zasady łączenia praw z obowiązkami powinno się przyczynić do zwiększenia efektywności finansowej systemu. Z kolei w krajach, w których świadczenia są mniej rozwinięte, władze powinny rozważyć przesunięcie środków publicznych na cele związane $\mathrm{z}$ doskonaleniem polityki flexicurity i pokrycie dodatkowych kosztów z różnych źródeł, m.in.: z wyższych podatków lub składek na zabezpieczenia społeczne.

Koszty wdrożenia modelu flexicurity należy jednak zawsze oceniać na tle korzyści, jakie odnosi budżet w związku ze zwiększoną dynamiką rynku pracy, wyższym zatrudnieniem i produktywnością. Wyniki jednej z analiz wskazują, że 10-procentowy wzrost nakładów na aktywną politykę rynku pracy na osobę powoduje obniżenie stopy bezrobocia o $0,4 \%$. Interwencja na wczesnym etapie ogranicza koszty długotrwałego bezrobocia, a także powiązane z nimi koszty pogorszenia się stanu zdrowia i wykluczenia społecznego ${ }^{10}$.

Poprawa systemów uczenia się przez całe życie również wymaga jeszcze bardziej efektywnego, a czasem zwiększonego wykorzystania środków publicznych i prywatnych, które jednak powinny się zwrócić dzięki zwiększeniu liczby miejsc pracy i wydajności. Szacuje się, że zarobki osób szkolących się w ramach pracy zawodowej są o 5\% wyższe od zarobków osób, które nie biorą udziału w szkoleniach ${ }^{11}$. Znaczną część kosztów szkoleń ponoszą obecnie pracodawcy, aczkolwiek w ostatnich latach podchodzą do tego ostrożnie, obawiając się, iż wyszkolony personel może zostać zatrudniony przez innego pracodawcę. Problem ten mógłby być złagodzony poprzez fundusze na szkolenia tworzone na poziomie branży. Oprócz funduszy branżowych warto także wykorzystywać politykę publiczną,

${ }^{9}$ Bassani and Duval, Employment Patterns in OECD Countries: Reassessing the Role of Policies and Institutions, OECD WP no. 35, 2006, s. 8.

${ }^{10}$ I. Beleva, Long-Term Unemployment as Social Exclusion, Human Development Report, UNDP 1997.

${ }^{11}$ De la Fuente and Ciccone, Human capital in a global and knowledge-based economy, maj 2002 . 
która może dodatkowo stymulować uczestnictwo w procesie uczenia się przez całe życie. Warte uwagi są tutaj takie rozwiązania, jak ulgi podatkowe dla osób, które same finansują swoje szkolenia i kursy. W większości krajów odpowiedzialność za inwestycje w zakresie uczenia się przez całe życie i korzystania $\mathrm{z}$ aktualnych ofert szkoleniowych przekazać można również pracownikom. Dlatego mogą oni także ponosić część kosztów, np. inwestując swój czas ${ }^{12}$.

Wzmocnienie aktywnej polityki rynku pracy może wymagać skoncentrowania dodatkowych środków w celu pokrycia kosztów zindywidualizowanych strategii i środków zapobiegawczych. Aby zwiększyć skuteczność polityki w tej dziedzinie, nie wystarczy jednak tylko zwiększyć wydatków. Skuteczność polityki zależy od jej jakości i dostosowania do potrzeb rynku pracy, od jej zindywidualizowania oraz od odpowiedniego połączenia bezpieczeństwa i gotowości do przyjęcia zmian i zaakceptowania dynamiki rynku pracy. Aktywną politykę rynku pracy dopełnia bowiem także skuteczna polityka w zakresie przeciwdziałania dyskryminacji.

Polityka w zakresie flexicurity często łączy się z kosztami dla budżetu i dlatego musi być w pełni kompatybilna ze stabilną i finansowo trwałą polityką budżetową. W niektórych krajach wydatki związane z flexicurity są wystarczająco wysokie, należy jednak zwiększyć ich efektywność, przede wszystkim poprzez udoskonalenie struktury polityki w zakresie uczenia się przez całe życie i aktywnej polityki rynku pracy. W innych państwach istnieje wyraźna potrzeba zwiększenia środków, a co za tym idzie - wydatków publicznych i prywatnych, przynajmniej w krótkiej perspektywie. Jednak dodatkowe fundusze niekoniecznie muszą łączyć się ze zwiększeniem wydatków publicznych - można je uzyskać także dzięki sprawiedliwemu podziałowi kosztów między przedsiębiorstwami, osobami prywatnymi i budżetem publicznym oraz dzięki przesunięciu środków pierwotnie przeznaczonych na finansowanie innych priorytetów polityki ${ }^{13}$.

We wspólnotowych wytycznych dotyczących spójności i rozwoju obszarów wiejskich podkreśla się wkład polityki spójności i rozwoju obszarów wiejskich w osiąganie strategicznych celów Unii, a przede wszystkim - Strategii Lizbońskiej. Działania wchodzące w zakres wytycznych na rzecz zatrudnienia (a więc również polityka w zakresie flexicurity) kwalifikują się do finansowania ze środków Europejskiego Funduszu Społecznego, które w okresie programowania 2007-2013 wyniosą 70 mld euro. W wielu przypadkach źródłem finansowego wsparcia może być także Europejski Fundusz Rozwoju Regionalnego. Do kwalifikujących się działań należą np. szkolenia w przedsiębiorstwach oraz środki aktywnej polityki rynku pracy, takie jak pomoc bezrobotnym w poszukiwaniu zatrudnienia, uczenie się przez całe życie, a także wspieranie samozatrudnienia i przedsiębiorczości.

\footnotetext{
${ }^{12}$ Wspólne zasady wdrażania modelu flexicurity..., s. 13.

${ }^{13}$ Ibidem, s. 14.
} 
Znaczący wkład Wspólnoty mogą również stanowić środki Europejskiego Funduszu Dostosowania do Globalizacji.

\section{ELEMENTY FLEXICURITY A POLSKI RYNEK PRACY - PRÓBA OCENY}

W przypadku Polski wciąż trudno jest mówić o istnieniu systemu flexicurity. Model wdrażania i funkcjonowania flexicurity w Polsce pozostaje nadal przedmiotem planowania i dyskusji. Porównanie polskiego rynku pracy w zakresie czterech komponentów modelu flexicurity $\mathrm{z}$ innymi krajami UE, a w szczególności z Danią, w której model ten jest stosowany z powodzeniem od 15 lat, pozwoli wskazać dystans, jaki polski rynek pracy ma wciąż do pokonania. Jednocześnie należy podkreślić, iż pomimo że każde państwo UE posiada swobodę w prowadzeniu swojej polityki zatrudnienia i dostosowuje ją do aktualnych tendencji gospodarczych, to jednak Unia Europejska w najbliższych latach wymagać będzie cyklicznych sprawozdań, dotyczących wdrażania flexicurity w każdym z krajów, tym samym stworzenie jasnego programu flexicurity w Polsce jest koniecznością.

Prowadzenie aktywnej polityki rynku pracy jest jednym z elementów modelu flexicurity i stanowi kluczowe działanie mające na celu zmniejszenie bezrobocia, a tym samym zwiększenie poziomu zatrudnienia. Do działań aktywnych zalicza się przede wszystkim szkolenia, roboty publiczne, doradztwo zawodowe, pośrednictwo pracy czy też zatrudnienie socjalne. Według danych OECD z 2005 roku, wydatki na programy rynku pracy np. w Danii wyniosły 4,26\% PKB, w Polsce zaś tylko $1,29 \% \mathrm{PKB}^{14}$. Dodatkowo w Polsce wciąż dominują programy pasywne. Łącznie na zasiłki i ubezpieczenia $\mathrm{z}$ tytułu bezrobocia oraz wczesne emerytury przeznaczono w 2005 roku blisko 0,9\% PKB. Powodem małej efektywności w tym obszarze jest system finansowania aktywnej polityki rynku pracy. Szansą na poprawę sytuacji może stać się zintensyfikowanie wykorzystania funduszy unijnych.

Elastyczność rynku pracy jest ideą przewodnią modelu flexicurity. Pomiar elastyczności umożliwia, opracowywany przez OECD i uniwersalny dla wszystkich krajów, Indeks Prawnej Ochrony Zatrudnienia (EPL - Employment Protection Legislation). Wskaźnik ten pozwala porównywać ochronny aspekt prawa pracy i oceniać potencjalną elastyczność rynku pracy w danym kraju. Indeks został skonstruowany na podstawie klasyfikacji 22 obszarów tematycznych, dotyczących regulacji zatrudnienia, takich jak np. długość okresu wypowiedzenia, warunki wypłacania odpraw czy też maksymalna liczba umów na czas określony, które mogą być zawarte przed umową na czas nieokreślony. Jednak najistotniejszą rolę składową indeksu EPL odgrywają 3 komponenty: regulacje dotyczące

\footnotetext{
${ }^{14}$ K. Belczyk, op. cit.
} 
ochrony zatrudnienia pracowników z umowami na czas nieokreślony, regulacje dotyczące ochrony zatrudnienia pracowników z umowami na czas określony oraz regulacje dotyczące ochrony zatrudnienia przed zwolnieniami grupowymi. Indeks EPL został oparty na skali od 0 do 6 . Im wyższa wartość wskaźnika, tym poziom regulacji przepisów i ochrona zatrudnienia są w danym kraju bardziej restrykcyjne, co skutkuje potencjalnie niższą elastycznością rynku pracy. Spośród krajów OECD najwyższym stopniem regulacji odznacza się Portugalia, a najniższy reprezentują Stany Zjednoczone. Wśród wszystkich państw skupionych w OECD Polska plasuje się w środku stawki. Przez lata 90. XX wieku indeks EPL dla Polski utrzymywał się na stałym poziomie zbliżonym do wartości $2,23{ }^{15}$. W Danii, gdzie w 1994 roku w duchu wdrażania modelu flexicurity weszły w życie nowe przepisy ograniczające ochronę zatrudnienia pracowników, ten sam wskaźnik spadł z 1,52 do 1,47 punktu. Niestety, badania przeprowadzane przez OECD sięgają jedynie roku 2003, dlatego podanie najnowszych wartości indeksu EPL nie jest możliwe. Niemniej jednak można przypuszczać, że wskaźnik EPL w Polsce zaczął spadać po 2003 roku z uwagi na postępujące uelastycznienie przepisów kodeksu pracy w latach 2004-2009.

Edukacja oraz stałe poszerzanie wiedzy i kompetencji wśród pracowników ma kluczowe znaczenie dla zwiększenia szans na utrzymanie zatrudnienia i oddalenie perspektywy bezrobocia. Kształcenie ustawiczne, czyli ciągłe podnoszenie swoich kwalifikacji poprzez uczestnictwo w różnego rodzaju szkoleniach, kursach i innych formach edukacji pozaszkolnej, stanowi ważny element w osiągnięciu zamierzonych celów flexicurity. Szybka i odpowiednia reakcja na zmiany rynkowe i innowacje wymaga wdrożenia kompleksowych strategii uczenia się przez całe życie i lepszych inwestycji w zasoby ludzkie. W tej dziedzinie przodują zwłaszcza kraje skandynawskie, a Polskę od liderów kształcenia ustawicznego dzieli ogromna przepaść. Dania może pochwalić się najwyższym w Europie odsetkiem osób, które biorą udział w formach kształcenia ustawicznego $(29,2 \%)^{16}$. Średnia dla 27 państw Unii Europejskiej w 2007 roku wyniosła 9,7\%. W Polsce w tym samym czasie w różnego rodzaju kursach, szkoleniach i innych formach aktywności edukacyjnej brało udział jedynie 5,1\% osób w wieku 25-64 lata. Wśród wszystkich państw UE niższy od Polski wskaźnik zanotowano jedynie w Bułgarii, Grecji, Słowacji i na Węgrzech. To, co charakterystyczne dla wszystkich analizowanych kategorii, to fakt, że w kształceniu ustawicznym zdecydowanie częściej uczestniczą kobiety niż mężczyźni ${ }^{17}$.

${ }^{15} \mathrm{http}: / /$ stats.oecd.org/wbos/index.aspx.

${ }^{16} \mathrm{D}$. Lang, Duński model elastycznego bezpieczeństwa. Wzór do naśladowania?, http://www. ips.uw.edu.pl/rszarf/pdf/lang.pdf.

${ }^{17} \mathrm{http} / / /$ epp.eurostat.ec.europa.eu/portal/page?_pageid=1090,30070682,1090_330765768_ $\mathrm{dad}=$ portal\&_schema=PORTAL. 
Kolejnym elementem modelu flexicurity jest nowoczesny system zabezpieczeń zapewniający świadczenia dla bezrobotnych. Jest to niezbędny element gwarantujący bezpieczeństwo finansowe i wsparcie w okresie zmiany bądź poszukiwania pracy. Wydatki publiczne przeznaczane na zabezpieczenie społeczne w Polsce znacznie odbiegają o tych oferowanych w większości państw Europy Zachodniej. Średnio w 25 państwach Unii Europejskiej w roku 2005 na różnego rodzaju świadczenia na zabezpieczenie społeczne przeznaczono ponad $27 \%$ PKB. Liderami pod tym względem pozostają państwa skandynawskie. W krajach takich jak Szwecja czy Dania blisko 1/3 dochodów Produktu Krajowego Brutto przeznacza się na sferę socjalną. W 2005 roku w Polsce wydatki na ten cel wyniosły 19,6\% PKB. Niższy odsetek wykazywały tylko kraje z Europy Środkowo-Wschodniej: Litwa, Łotwa, Estonia, Czechy, Słowacja, Bułgaria, Rumunia, oraz Irlandia i $\mathrm{Cypr}^{18}$.

\section{ZAKOŃCZENIE}

Model flexicurity staje się coraz popularniejszy w Europie, w tym także w Polsce trwa proces jego wdrażania zgodnie ze wspólnymi zasadami promowanymi przez Unię Europejską. Niemniej jednak przeprowadzona powyżej ogólna ocena czterech niezbędnych elementów modelu wskazuje jednak, że Polska wciąż znacznie odbiega od innych krajów unijnych w poziomie wskaźników opisujących intensywność stosowania modelu flexicurity. We wszystkich czterech analizowanych obszarach Polska ma wciąż znaczne opóźnienie i polityka państwa powinna zostać ukierunkowana m.in. na stworzenie spójnego (szczególnie w zakresie prawa pracy i systemu zabezpieczeń społecznych) modelu polskiego flexicurity, a następnie etapów jego wdrażania. Należy tu podkreślić, że polityka państwa nie może tworzyć sprzecznych bodźców dla obu stron stosunku pracy np. wtedy, gdy koszty zatrudniania $\mathrm{w}$ formach nietypowych są dla pracodawcy znacznie niższe, a równocześnie „nietypowi pracownicy” mają ograniczony dostęp do świadczeń z systemu zabezpieczenia społecznego. Potrzebne jest wypracowanie równowagi praw i obowiązków pracowników oraz przedsiębiorców, a także organów publicznych, gdyż tylko współdziałanie wszystkich stron pozwoli upowszechnić ten model i jego korzystne skutki dla gospodarki, pracowników i przedsiębiorstw.

Barierą $\mathrm{w}$ przekształceniu funkcjonowania polskiego rynku pracy są przede wszystkim finanse państwa. Wzrost nakładów na zabezpieczenie społeczne i aktywną politykę rynku pracy może być zagrożeniem dla i tak nadwyrężonego budżetu. Szansę na pozytywne zmiany w zakresie przyspieszenia wdrażania modelu

\footnotetext{
${ }^{18}$ Ibidem.
} 
flexicurity w Polsce stanowić jednak mogą instrumenty finansowe Unii Europejskiej, a w szczególności Europejski Fundusz Społeczny na lata 2007-2013. Idea flexicurity jest upowszechniana m.in.: w ramach poddziałania 8.1.3 Programu Operacyjnego Kapitał Ludzki, pod nazwą „Wzmacnianie lokalnego partnerstwa na rzecz adaptacyjności”. Głównym celem tego priorytetu jest rozwój wykwalifikowanej i zdolnej do adaptacji siły roboczej oraz poprawa funkcjonowania systemu przewidywania i zarządzania zmianą gospodarczą. Środki mają być kierowane głównie na szkolenia na poziomie przedsiębiorstw, programy uczenia się przez całe życie oraz promocję przedsiębiorczości.

Wspólne strategie z obszaru flexicurity promowane przez Komisję Europejską mogą więc w kolejnych latach przyczynić się do znacznej modernizacji rynków pracy w Europie oraz do skuteczniejszego sprostania wyzwaniom związanym z globalizacją i wykorzystania tworzonych przez nią szans i możliwości oraz przeciwdziałania zagrożeniom.

\section{IMPLEMENTATION OF THE FLEXICURITY MODEL IN POLAND AS A RESPONSE TO MODERN LABOUR MARKET CHALLENGES}

SUMMARY

The flexibility of labour markets has been facilitated by the globalisation processes, social and cultural developments, the advancement of technology and telecommunications as well as the fast expansion of the service sector. The resulting labour market developments include the liberalisation of labour laws and the spread of more flexible forms of employment. On the one hand, those changes provide an additional competitive edge to businesses and national economies, while on the other they also create problems with the social security of persons employed on flexible terms. The proposed measure to alleviate these problems is the application of the flexicurity model, which integrates the increased flexibility of employment with a simultaneous enhancement of employee security.

The article presents the components of the flexicurity model and attempts to evaluate their advancement in the Polish labour market. This is done against the background of the basic principles, characteristics and benefits of fexicurity implementation. Additionally, the common principles and the system of financing the flexicurity model implementation within the EU are discussed. 